\title{
Trip characteristics as the determinants of intention to shift to rail transport among private motor vehicle users in Kuala Lumpur, Malaysia
}

\author{
Soo Chen Kwan ${ }^{\mathrm{a}, \mathrm{b}, *}$, Rosnah Sutan ${ }^{\mathrm{b}}$, Jamal Hisham Hashim ${ }^{\mathrm{a}}$ \\ a United Nations University - International Institute for Global Health, Kuala Lumpur, Malaysia \\ b Department of Community Health, National University of Malaysia, Kuala Lumpur, Malaysia
}

\section{A R T I C L E I N F O}

\section{Keywords:}

Private vehicle

Urban rail transport

Trip characteristics

Intention to shift

\begin{abstract}
A B S T R A C T
Introduction: This study aims to understand the trip characteristics of private and public transport users in Kuala Lumpur, and the intention of private motor vehicle users to shift to rail transport if available.

Method: We conducted a travel survey in the corridor of an upcoming mass rapid transit line in Kuala Lumpur. We then analyse the characteristics of the trips recorded from the survey on a weekday and weekend. We used binary logistic regression to find the association between the trip characteristics and the intention to shift from private motor vehicles to rail transport if available.

Results: There were less than $15 \%$ of public transport users among the survey respondents. However, $48 \%$ of the weekday trips and $39 \%$ of the weekend trips were intended to shift to rail transport if available. Regression for the weekday trips showed that trip duration, distance, purpose, vehicle occupancy, and presence of child passengers were significantly associated with the intention to shift. For weekend trips, only the trip duration and presence of child passengers were significantly associated with the intention to shift.

Conclusion: This study shows that the population's intention to shift from private motor vehicle to rail transport could be influenced by the trip characteristics.
\end{abstract}

\section{Introduction}

Urban transportation is an issue of concern in cities worldwide. Urban agglomeration with inadequate public transport network has caused people to turn to automobile for transport. Such phenomenon contributes to both social economic burden and large emissions of carbon dioxide and environmental pollutions (Chapman, 2007; Krzyzanowski et al., 2005). Besides, the motor vehicle traffic could adversely affect the citizens' health through air pollution, noise disturbances and the involuntary uptake of sedentary lifestyle (Khreis et al., 2016; Babisch, 2006; Lachapelle, Frank, Saelens, Sallis, \& Conway, 2011).

In Kuala Lumpur, the spillover effect of the population to the urban outskirts has caused increased traffic entering the city daily. The Kuala Lumpur metropolitan area or Greater Kuala Lumpur covers Kuala Lumpur itself, and nine other local governments in the neighbouring Selangor state. The urban sprawl due to decentralization has increased car dependency as many places do not have access to public transport (Kasipillai and Chan, 2008). During the morning peak hours, $70 \%$ of the traffic on major roads were single occupancy cars, which proves an extremely inefficient way of travelling in the city (Mohamad and
Kiggundu, 2007). Consequently, forests were cleared to build more roads to accommodate the large volume of vehicle traffic. Such situation clearly connotes the need for an urgent improvement of transport system in the city.

Public transport is an important element in the global propagation towards sustainable transport. Compared to the neighboring Asian countries, Malaysia has a relatively low rate of public transport usage (Almselati, Rahmat, \& Jaafar, 2011). The modal share of public transport had reduced considerably from $34 \%$ in $1985-10 \%$ in 2008 (Performance management delivery unit (PEMANDU), 2010). Based on Jemali (2011), 83\% or 6 million trips in the Kuala Lumpur metropolitan area were made on private motor vehicles, while only $17 \%$ or 1.24 million trips were made by public transport. This was partly due to the insufficient public transport network, where only $10 \%$ to $20 \%$ of the urban areas were accessible by rail transit (Ministry of Natural Resources and Environment Malaysia (NRE), 2011). Nonetheless, rail transport constituted $52 \%$ of the public transport modal share (Land Public Transport Commission (SPAD), 2014). Therefore, the government has put in concerted efforts under the Land Public Transport Master Plan to improve the public transport infrastructure in Kuala Lumpur (Land Public Transport Commission (SPAD), 2013).

\footnotetext{
* Corresponding author at: United Nations University - International Institute for Global Health, Kuala Lumpur, Malaysia

E-mail address: sc.kwan@yahoo.com (S.C. Kwan).
} 
Transport modal choice can be influenced by personal characteristics, trip characteristics and attributes of the environment such as land use, accessibility and availability of transit services (Ortúzar, de, \& Willumsen, 2001; Racca \& Ratledge, 2003). Other factors include the local psychosocial values, mobility biographies due to life-course transitions, and national economic policies (Chowdhury and Ceder, 2016; Müggenburg, Busch-Geertsema, \& Lanzendorf, 2015). This paper focuses mainly on the influence of vehicle trip characteristics on the users' intention to shift to rail transport. Previous studies in different cities have shown that transport modal shift could be influenced by: the original transport mode, trip frequency, geographical location, trip distance, trip duration, cost, and purpose of trips (Wang et al., 2012; Kumar and Electricwala, 2014; van der Waerden, Timmermans, \& Berenos, 2008; Wang, Li, Wang, Lv, \& Wang, 2013). An Australian study indicated that public transport use was induced by parking problems, and vehicle accessibility especially among students (Corpuz, 2007). In Malaysia, studies by Nurdden et al. (2007) and Chuen et al. (2014) revealed that the preference towards public transport could be encouraged by fare subsidy, reduced transit time, reduced distance from home to transit stations, and home to work location.

As Malaysia aims for sustainable transport, it is necessary to understand the current trip characteristics in Kuala Lumpur in order to formulate effective transport strategies. In Malaysia, there is a lack of published studies on the local trip characteristics and their influences on modal shift. At the advent of a Mass Rapid Transit (MRT) infrastructure in the Kuala Lumpur metropolitan area, we took the opportunity to examine the trips characteristics of private motor vehicles in the corridor of the MRT line, and their association with the public's intention to shift to rail transport. The $51 \mathrm{~km}$ MRT Sungai Buloh Kajang (SBK) line is the first MRT infrastructure in Malaysia. It has 31 stations and an expected daily ridership of 400,000 people. During this study, the large scale construction of the MRT track, which started in 2011 was in the middle construction stage.

\section{Method}

A cross sectional questionnaire survey was conducted on the local population in the corridor of the MRT (SBK) line by multistage sampling. First, we systematically sampled eight out of the 31 MRT stations. Then, we chose the supermarkets that were situated within five kilometres relative to these sampled MRT stations, which were then still under construction. An intercept survey was done to get the respondents at the supermarkets. The locations of the supermarkets are shown in Fig. 1. There were only seven locations shown in the map because one of the supermarkets chosen (S6) was situated within $5 \mathrm{~km}$ to two MRT stations, and there were no other suitable locations in the area. We chose local supermarkets as our survey locations in order to approach the household residents in the area. This is because it is expected that most of the MRT users would be the local residents as $90 \%$ of the property units within $500 \mathrm{~m}$ of the MRT line were residential houses (Detailed Environmental Impact Assessment report (EIA), 2011). We conducted the questionnaire survey on weekends when most people do grocery shopping. The respondents were interviewed face to face, and given a small token of appreciation at the end of the $10 \mathrm{~min}$ questionnaire. The questionnaire survey was done between February 2015 and June 2015.

The questionnaire included the respondents' demographic background and trip characteristics on a conventional weekday and weekend. The trip characteristics form was adapted from the template of travel diary used in Boulder Valley (National Research Center, 2013). The questionnaire in English was translated to Malay language back to back, and pretested before use to ensure that it is easily understandable, and the trip attributes such as trip purposes were suitable for the local context. The respondents were directed to recall the trips made on the closest regular weekday (e.g. Thursday), and the previous weekend before the interview. The trip characteristics enquired included destinations, transport mode, trip duration, trip distance, vehicle occupancy for private vehicle users and the presence of child passengers (age < 18). At the end of the descriptions of each trips, we added a column asking the respondents' intention to shift each particular private vehicle trips to rail transport if available (Fig. 2). Due to some respondents being unsure of their trip distance, we applied Google maps to estimate the kilometers travelled by the respondents, using the shortest distance to the destinations.

We applied IBM SPSS version 22 for data analysis. From the trips recorded, we analysed the modal share and compared the trip characteristics between the private motor vehicle and public transport using Kruskal Wallis $\mathrm{H}$ test, followed by Mann-Whitney U pairwise comparison for non-parametric analysis. A backward stepwise binary logistic regression was run to identify the trip characteristics that were associated with the intention to shift from private motor vehicles to rail transport if available.

\section{Results}

\subsection{Socio-demographic characteristics of respondents}

A total of 509 respondents were interviewed. Table 1 shows the socio-demographic characteristics of the survey respondents. Most of the respondents fell within the age range of 18-29 (35.4\%) and 30-39 $(32.6 \%)$. Each gender (male and female) constituted half of the total respondents, with majority from the ethnicity of Malay (65.0\%) followed by Chinese (24.4\%), Indian (4.9\%) and others (5.7\%). A large proportion of the respondents were married $(70.5 \%)$ and about half of them $(55.0 \%)$ have children below 18 years old. There were $42.6 \%$ of the respondents with education above the degree level, followed by $29.3 \%$ with college level and $28.1 \%$ at secondary school level and below. The highest percentage of income group was in the range of RM $2001-4000$ (31.8\%), followed by RM $6000+(27.1 \%)$.

\subsection{Modal share}

The respondents were asked about their conventional trips on a weekday and a weekend. Among the respondents, there were 35 and 102 people who reported making no trips on the weekday and weekend, respectively, and were excluded. The respondents were then separated according to their main transport mode, which were determined by the transport mode of their longest journey on the day. Results show that more than half of the respondents used car $(63.7 \%)$ for their main journeys on the weekday, followed by motorcycle (18.8\%), rail (10.3\%) and bus (2.7\%). For the weekend, there were more respondents using car (86\%), followed by $5.4 \%$ rail, $3.2 \%$ motorcycle, and $2 \%$ bus. There was less public transport use on the weekend than the weekday.

Overall, we recorded 1615 trips on the weekday and 1110 trips on the weekend from the respondents. We excluded outstation trips and included only trips within the Kuala Lumpur metropolitan area. On the weekday, $61.4 \%$ of the trips were made by car, followed by $15.8 \%$ by motorcycle, $6.7 \%$ by rail and $3.8 \%$ by bus. On the weekend, $77.4 \%$ of the trips were made by car, followed by $4.9 \%$ by rail, $4.2 \%$ by motorcycle, and $2.9 \%$ by bus. Walking trips, which mostly came from walking to and from the public transit stations, were at $11.0 \%$ and $9.2 \%$ on the weekday and weekend, respectively. For the binary logistic regression analysis on private vehicle users' intention to shift to rail transport, we used the trips recorded under the respondents whose main transport were car driver, car passenger and motorcycle. This was to exclude the motor vehicle trips made by public transport (rail and bus) users who drove or rode to stations. The percentages of the trips by transport mode are presented in Table 2. 


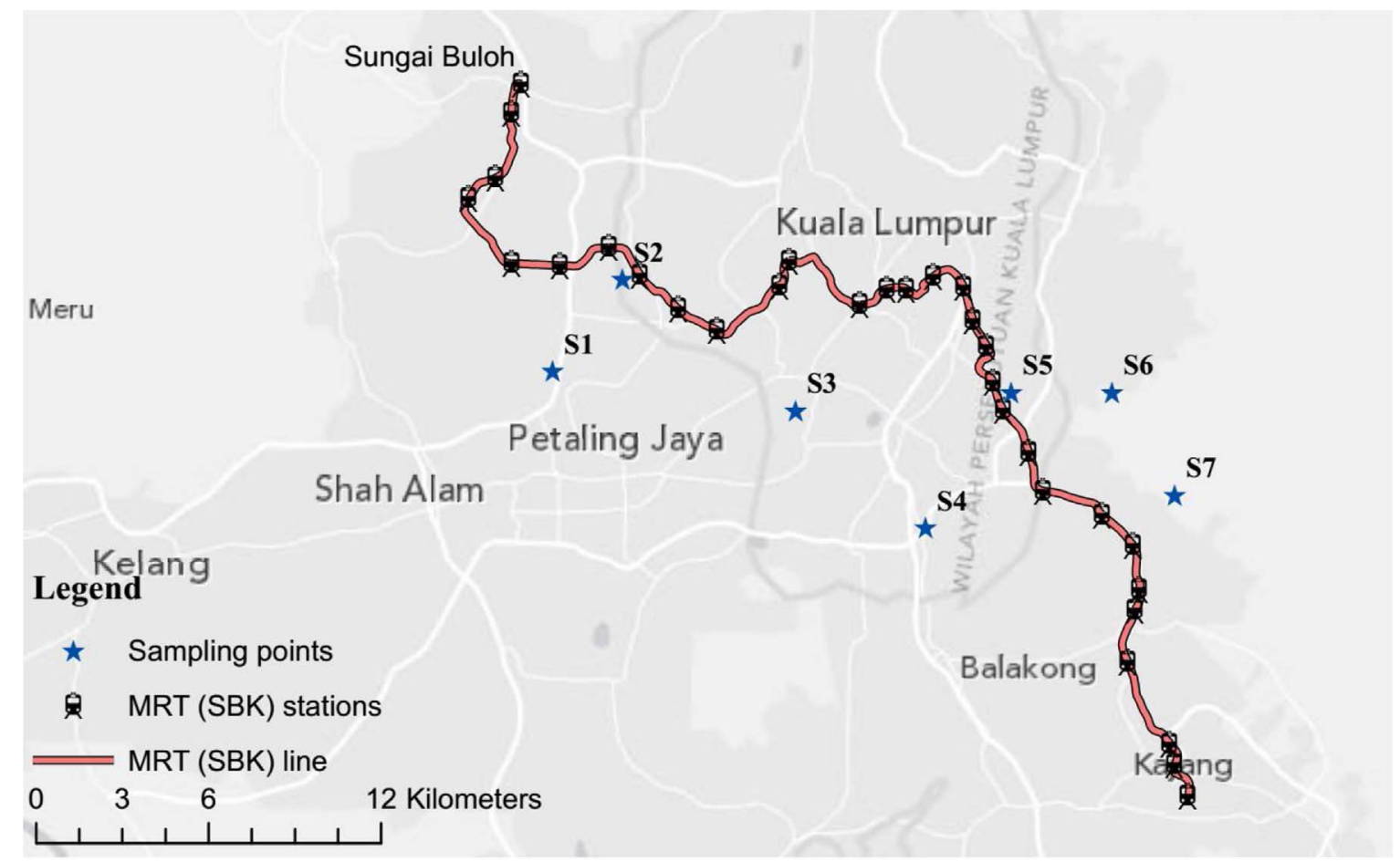

Fig. 1. The MRT (SBK) line and the sampling locations (S1-S7).

\begin{tabular}{|c|c|c|c|c|c|c|c|c|c|}
\hline $\begin{array}{l}\text { Trip } \\
\#\end{array}$ & $\begin{array}{l}\text { Destination (name } \\
\text { of place/road/ } \\
\text { building) }\end{array}$ & $\begin{array}{l}\text { Journey } \\
\text { time }\end{array}$ & km & \multicolumn{2}{|c|}{$\begin{array}{c}\text { Trip Method } \\
\text { (circle the option) }\end{array}$} & \multicolumn{2}{|c|}{$\begin{array}{l}\text { Trip Purpose (main purpose) } \\
\text { (circle the option) }\end{array}$} & $\begin{array}{l}\text { No. people } \\
\text { in vehicle } \\
\text { (inc.yourself) }\end{array}$ & $\begin{array}{l}\text { Intend to shift to } \\
\text { MRT/LRT } \\
\text { IF available }\end{array}$ \\
\hline 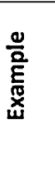 & $\begin{array}{l}\text { Primary School } \\
\text { Jalan Davidson }\end{array}$ & $\begin{array}{c}\frac{7.00}{-} \\
7.15 \\
\text { am } 8 \mathrm{pm}\end{array}$ & 3 & $\begin{array}{l}\text { 1. Dar (driver) } \\
\text { 2. car (passenger) } \\
\text { 3. motorcycle } \\
\text { 4. bus (no.: } \\
\text { 5. rail (st.: } \\
\text { 6. taxi }\end{array}$ & $\begin{array}{l}\text { 7. walk } \\
\text { 8. bicycle } \\
\text { 9. commercial } \\
\text { truck } \\
\text { 10. other: }\end{array}$ & $\begin{array}{l}\text { 1. go home } \\
\text { 2. work commute } \\
\text { 3. Drive passenger } \\
\text { 4. school } \\
\text { 5. eat a meal } \\
\text { 6. shopping }\end{array}$ & $\begin{array}{l}\text { 7. change travel mode } \\
\text { (e.g. bus/LRT station) } \\
\text { 8. social/recreation } \\
\text { 9. other work/business } \\
\text { 10. personal business } \\
\text { 11. other: }\end{array}$ & $\begin{array}{l}\text { adult :_1 } \\
\text { children:_1_- } \\
\text { age:_11_i_- }\end{array}$ & $\begin{array}{l}\text { Yess } \mathrm{No} / \mathrm{NA} \\
\text { Why: }\end{array}$ \\
\hline
\end{tabular}

Fig. 2. Sample questionnaire of trip characteristics and intention to shift.

\subsection{Trip characteristics}

Table 3 shows the distance, duration and speed of the trips made by private motor vehicles and public transports. For private vehicles on the weekday, the median trip distance ranged from $9.8 \mathrm{~km}$ to $10.6 \mathrm{~km}$, which took $20.0 \mathrm{~min}$ to $30.0 \mathrm{~min}$ per trip, and gave a median speed ranging from 24.0 to $31.8 \mathrm{~km} /$ hour. On the weekend, the range of trip distance were wider from $5.0 \mathrm{~km}$ to $14.5 \mathrm{~km}$, which took $15.0 \mathrm{~min}$ to $30.0 \mathrm{~min}$ per trip, and gave a median speed at $30 \mathrm{~km} /$ hour. For public transport on the weekday, the trip distance for rail and bus were $10.5 \mathrm{~km}$ and $4.7 \mathrm{~km}$, respectively, with the same trip duration at $20 \mathrm{~min}$ per trip. Thereby, the speed for rail was at $33 \mathrm{~km} /$ hour, which was double that of bus at $15.6 \mathrm{~km} /$ hour. On the weekend, the trip distance for rail and bus were $7.9 \mathrm{~km}$ and $11.1 \mathrm{~km}$, respectively, with the trip duration ranging from $15.0 \mathrm{~min}$ to $30 \mathrm{~min}$, which also made rail trips two times faster than bus trips. The trip characteristics for transits and other transport modes such as walking, cycling and taxi are presented in Table A.1, Supplementary material.

The distributions of the vehicle kilometre travelled per trip for private motor vehicles on a weekday and weekend were skewed to the right (Fig. A.1, Supplementary material). Comparisons of trip characteristics between the transport modes were done using Kruskal Wallis $\mathrm{H}$ and Mann Whitney $U$ tests. For weekday, Kruskal Wallis $\mathrm{H}$ test indicated that trip duration and speed were significantly different between the private transport modes (Table 3). Mann Whitney U pairwise comparison further elucidated that motorcycle trips had significantly higher speed than car driver's trips, and lower trip duration than all car trips (Table A.2, Supplementary material). Trip distance was not significantly different between the private transport modes. For public transport, rail trips had significantly longer trip distance and higher speed compared to bus trips (Table 3). Comparison between private vehicles (car driver, passenger and motorcycle) and public transport (rail, bus) on the weekday indicated that rail trips had significantly higher speed than car driver's trips, while motorcycle trips had significantly higher speed than bus trips. No significance was found for trip duration and trip distance (Table A.3, Supplementary material).

For the weekend trips, Kruskal Wallis $\mathrm{H}$ test revealed significant difference in trip distance and trip duration between the private transport. Mann Whitney U pairwise comparison showed that motorcycle trip distance were significantly less than car trips, with significantly shorter trip duration (Table A.4, Supplementary material). For public transport, rail trips had significantly lower trip duration with higher speed compared to bus trips. Comparison between private and public transport on weekend indicated that the speed for bus was significantly lower than all the private vehicle modes (car driver, car passenger and motorcycle) (Table A.5, Supplementary material). In addition, bus also had significantly longer trip duration than motorcycle, while rail trips had significantly shorter trip duration than all the private vehicle modes. Car passenger trips also had significantly longer trip distance than the rail trips.

The trip purposes were grouped into five main categories for the weekday's trips (Table 4). Due to the small percentage of work commute and school trips on the weekend, we combined it with the purpose of driving passenger. Results show that most of the trips were work 
Table 1

Socio-demography of respondents.

\begin{tabular}{|c|c|c|c|}
\hline Variables & $\mathrm{N}=509$ & $\%$ & Mean (SD) \\
\hline Age & & & 35.25 (11.514) \\
\hline $18-29$ & 180 & 35.4 & \\
\hline $30-39$ & 166 & 32.6 & \\
\hline $40-49$ & 96 & 18.9 & \\
\hline $50+$ & 67 & 13.2 & \\
\hline \multicolumn{4}{|l|}{ Ethnic } \\
\hline Malay & 331 & 65.0 & \\
\hline Chinese & 124 & 24.4 & \\
\hline Indian & 25 & 4.9 & \\
\hline Others & 29 & 5.7 & \\
\hline \multicolumn{4}{|l|}{ Education level } \\
\hline$\leq$ secondary & 143 & 28.1 & \\
\hline College & 149 & 29.3 & \\
\hline$\geq$ degree & 217 & 42.6 & \\
\hline \multicolumn{4}{|l|}{ Income level (RM) } \\
\hline$\leq 2000$ & 94 & 18.5 & \\
\hline $2001-4000$ & 162 & 31.8 & \\
\hline $4001-6000$ & 115 & 22.6 & \\
\hline $6001+$ & 138 & 27.1 & \\
\hline \multicolumn{4}{|l|}{ Gender } \\
\hline Male & 257 & 50.5 & \\
\hline Female & 252 & 49.5 & \\
\hline \multicolumn{4}{|l|}{ Status } \\
\hline Single & 150 & 29.5 & \\
\hline Married & 359 & 70.5 & \\
\hline Child (age < 18) & & & 2.16 (1.027) \\
\hline No & 229 & 45.0 & \\
\hline Yes & 280 & 55.0 & \\
\hline
\end{tabular}

commute (26.4\%) on the weekday, and having a meal/shopping/leisure activities (42.5\%) on the weekend. Kruskal Wallis $\mathrm{H}$ test shows that there were significant difference between all trip characteristics except for speed on the weekend. Mann-Whitney $U$ test found that the trips for both work commute and other work/personal business had significantly higher median trip duration, distance and speed than both driving passenger/school trips and meal/shopping/leisure trips, except for speed between other work/personal business and meal/shopping/ leisure trips (Table A.6, Supplementary material). No significant difference was found between trips for the purpose of work commute and other work/personal business; and between driving passenger/school and meal/shopping/leisure trips on the weekday. On the weekend, other work/personal business has significantly higher trip duration than both work commute and meal/shopping/leisure trips, and significantly higher trip distance than meal/shopping/leisure trips. No significant difference was found between work commute trips and meal/shopping/leisure trips on the weekend.

For vehicle occupancy, there was a median of one to two persons per car on the weekday, and three persons per car on the weekend (Table 5). Motorcycles had one person per vehicle on both the weekday and weekend. Child passengers (age $<18$ ) were present in a quarter of the weekday trips, and half of the weekend trips by car.

\subsection{Intention to shift for private motor vehicle trips}

Our analysis shows that an overall $47.6 \%$ of the weekday trips and $38.6 \%$ of the weekend trips were intended to be shifted to rail transport if available. Backward stepwise binary logistic regression model was performed to find the significant trip characteristics associated with the intention to shift to rail transport if available among the private vehicle users. Tables 6 and 7 show the regression results for the weekday and weekend trips. In the models, trip duration, trip distance and vehicle occupancy were categorized based on quartiles due to non-linearity of logit.

For the weekday trips, the model revealed that trip duration, trip distance, trip purpose, vehicle occupancy and presence of child passengers (age $<18$ ) were significantly associated with the intention to shift. The full model containing the predictors was statistically significant, $\mathrm{x}^{2}(13, \mathrm{n}=1185)=170.639, \mathrm{p}<0.001$, explaining between $13.4 \%$ (Cox and Snell $\mathrm{R}^{2}$ ) to $17.9 \%$ (Nagelkerke $\mathrm{R}^{2}$ ) of the variance in intention to shift, and correctly classified $65.6 \%$ of the trips. Although speed and transport mode of the trips were omitted from the model for model parsimony, simple logistic regression showed that the odds of the intention to shift decreased with increasing speed of the private motor vehicle trips, and for the motorcycle trips compared to the car trips (Table A.7, Supplementary material).

The full regression model shows that trip duration was the most important factor associated with the intention to shift, followed by trip distance and trip purpose. The respondents' intention to shift increased with travel time, with the $36+$ min trip having two times higher odds of intention to shift $(\mathrm{OR}=4.20, \mathrm{p}<0.001)$ than the $11-20$ min trip $(\mathrm{OR}=2.39, \mathrm{p}<0.001)$. However, increased trip distance reduced the respondents' intention to shift. The odds of the intention to shift increased for trips within 4.11-10 km (OR $=2.04$, p $<0.001)$ but reduced as the trip distance got beyond $10 \mathrm{~km}$. Respondents in trips with two persons in the vehicle $(\mathrm{OR}=1.53, \mathrm{p}=0.024)$ also had higher intention to shift than a single occupancy vehicle. For purpose, the OR of below 1 indicates that respondents had significantly less intention to shift for the purpose of socio-recreational trips (OR $=0.69, \mathrm{p}<0.01$ ). Having children in the vehicle also significantly reduced the respondent's intention to shift $(\mathrm{OR}=0.48, \mathrm{p}<0.01)$.

For the weekend trips, only trip duration and presence of child passengers remained as the significant trip characteristics associated with the intention to shift, although simple logistic regression also showed trip distance as the significant factor (Table A.8, Supplementary material). The full model containing the predictors was statistically significant, $\mathrm{x}^{2}(1, \mathrm{n}=880)=170.639, \mathrm{p}<0.001$, explaining between $4.4 \%$ (Cox and Snell $\mathrm{R}^{2}$ ) to $6.0 \%$ (Nagelkerke $\mathrm{R}^{2}$ ) of the variance in intention to shift, and correctly classified $61.6 \%$ of trips. The model shows that respondents had significantly higher intention to shift when the travel time increased, especially to above $36 \mathrm{~min}$ ( $\mathrm{OR}=2.68$,

Table 2

Percentage modal share on a weekday and weekend.

\begin{tabular}{|c|c|c|c|c|c|c|}
\hline \multirow[t]{2}{*}{ Transport mode } & \multicolumn{2}{|l|}{ Respondents (\%) } & \multicolumn{2}{|l|}{ Trips (\%) } & \multicolumn{2}{|c|}{ Private motorised trips (\%) } \\
\hline & Weekday $(\mathrm{n}=474)$ & Weekend $(n=407)$ & Weekday $(\mathrm{n}=1615)$ & Weekend $(\mathrm{n}=1110)$ & Weekday $(\mathrm{n}=1185)$ & Weekend $(\mathrm{n}=880)$ \\
\hline Car driver & 58.2 & 64.1 & 54.8 & 59.2 & 72.5 & 73.3 \\
\hline Car passenger & 5.5 & 22.1 & 6.6 & 18.2 & 6.7 & 22.0 \\
\hline Motorcycle & 18.8 & 3.2 & 15.8 & 4.2 & 20.8 & 4.7 \\
\hline Bus & 2.7 & 2.0 & 3.8 & 2.9 & & \\
\hline Rail & 10.3 & 5.4 & 6.7 & 4.9 & & \\
\hline Taxi & 0.6 & 1.0 & 1.1 & 1.4 & & \\
\hline Walk & 3.6 & 2.2 & 11.0 & 9.2 & & \\
\hline Cycle & 0.2 & 0.0 & 0.2 & 0.0 & & \\
\hline
\end{tabular}


Table 3

Comparisons of trip characteristics by transport modes on the weekday and weekend.

\begin{tabular}{|c|c|c|c|c|c|c|c|c|c|c|}
\hline & \multirow[t]{2}{*}{ Trips (n) } & \multicolumn{3}{|c|}{ Kilometres/trip } & \multicolumn{3}{|c|}{ Minutes/trip } & \multicolumn{3}{|c|}{ Speed (km/hour) } \\
\hline & & $\tilde{x}$ & IQR & $\mathrm{p}$ & $\tilde{x}$ & IQR & $\mathrm{p}$ & $\tilde{x}$ & IQR & $\mathrm{p}$ \\
\hline \multicolumn{11}{|c|}{ Weekday $(\mathrm{N}=1317)$} \\
\hline Private vehicles & & & & $0.228^{\mathrm{a}}$ & & & $<0.001^{\mathrm{a}}$ & & & $<0.001^{\mathrm{a}}$ \\
\hline Car driver & 859 & 10.0 & 13.8 & & 20.0 & 30.0 & & 24.0 & 21.0 & \\
\hline Car passenger & 79 & 10.6 & 19.9 & & 25.0 & 20.0 & & 30.0 & 22.2 & \\
\hline Motorcyclist & 247 & 9.8 & 16.4 & & 18.0 & 20.0 & & 31.8 & 27.0 & \\
\hline Public transport & & & & $0.025^{\mathrm{b}}$ & & & $0.407^{b}$ & & & $0.001^{\mathrm{b}}$ \\
\hline Rail & 108 & 10.5 & 10.6 & & 20.0 & 15.5 & & 33.0 & 21.6 & \\
\hline Bus & 24 & 4.7 & 12.0 & & 20.0 & 15.0 & & 15.6 & 23.4 & \\
\hline \multicolumn{11}{|c|}{ Weekend $(\mathrm{N}=953)$} \\
\hline Private vehicles & & & & $<0.001^{\mathrm{a}}$ & & & $<0.001^{\mathrm{a}}$ & & & $0.362^{\mathrm{a}}$ \\
\hline Car driver & 645 & 12.3 & 13.7 & & 20.0 & 15.0 & & 30.0 & 24.6 & \\
\hline Car passenger & 194 & 14.5 & 14.3 & & 30.0 & 30.0 & & 30.0 & 25.2 & \\
\hline Motorcyclist & 41 & 5.0 & 10.7 & & 10.0 & 12.5 & & 30.0 & 27.0 & \\
\hline Public transport & & & & $0.995^{b}$ & & & $<0.001^{\mathrm{b}}$ & & & $<0.001^{\mathrm{b}}$ \\
\hline Rail & 55 & 7.9 & 11.5 & & 15.0 & 17.5 & & 34.8 & 18.6 & \\
\hline Bus & 18 & 11.1 & 8.7 & & 30.0 & 40.0 & & 18.0 & 13.8 & \\
\hline
\end{tabular}

${ }^{\text {a }}$ Kruskal Wallis $\mathrm{H}$ test ${ }^{\mathrm{b}}$ Mann-Whitney $U$ test.

$\mathrm{p}<0.001)$. However, having children in the vehicle significantly reduced the respondents' intention to shift (OR $=0.68, \mathrm{p}<0.01)$.

\section{Discussion}

This study presents the general transport modal share, trip characteristics of the private and public transport, and the association between the trip characteristics of private transport and the respondents' intention to shift to rail transport in the corridor of an impending MRT line in the Kuala Lumpur metropolitan area. The distribution of the age, gender and ethnicity of the respondents reflected that of the Malaysian socio-demographic profile (Department of Statistics Malaysia, 2010). However, there was an overrepresentation of married respondents $(70 \%)$ in the survey compared to the national statistics (60\%), probably due to the nature of the survey location at supermarkets. The number of respondents with an education of above degree level in this study (43\%) was also higher than the national average (17\%) (Institute for Public Health, 2015), possibly due to the urban setting. Besides, the underreporting of income prevailed, which was assumed to be uniform across all income categories.

The modal share of public transport was very low both on the weekday and weekend, which might have been caused by the insufficient public transport services in Kuala Lumpur, apart from the local car dependent culture. This justifies the introduction of the MRT stations in the area. Nonetheless, the modal share of rail transport was still higher than the bus. The reduced tendency to use bus services
Table 5

Vehicle occupancy by transport mode and the presence of child passengers.

\begin{tabular}{llllll}
\hline \multicolumn{3}{c}{ Weekday } & & & Weekend \\
\cline { 1 - 2 } \cline { 5 - 6 } Transport mode & $\begin{array}{l}\text { Vehicle } \\
\text { occupancy }\end{array}$ & $\begin{array}{l}\text { Presence of } \\
\text { child } \\
\text { passengers (\%) }\end{array}$ & & $\begin{array}{l}\text { Vehicle } \\
\text { occupancy }\end{array}$ & $\begin{array}{l}\text { Presence of } \\
\text { child } \\
\text { passengers (\%) }\end{array}$ \\
\hline Car driver & 1 & 25.6 & 3 & 51.8 \\
Car passenger & 2 & 26.6 & 3 & 55.2 \\
Motorcycle & 1 & 9.3 & 1 & 14.6 \\
\hline
\end{tabular}

among the population could be explained by its significantly lower speed compared to all other transport modes. On the other hand, utilitarian walking and cycling only made up a small part of the overall trips as they are still generally considered as leisure activities rather than transportations due to the insufficient infrastructures in Kuala Lumpur. However, public transport contributed quite a number of walking trips in accessing the rail or bus stations (Table A.1, Supplementary material). This indicates an opportunity to increase physical activity among the population when the MRT commences in the area (Kwan, Tainio, Woodcock, Sutan, \& Hashim, 2017).

For trip characteristics, motorcycles had the same trip distance as cars on the weekday, but much shorter distance on the weekend. This suggests that motorcycles have been used to substitute cars to travel on the weekday due to its ability to manoeuvre between traffic, and thus its higher speed which reduces travel time. Such situation connotes that

Table 4

Kruskal-Wallis test of trip characteristics based on trip purpose on the weekday and weekend.

\begin{tabular}{|c|c|c|c|c|c|c|c|c|c|c|}
\hline \multirow[t]{2}{*}{ Purpose } & \multirow[t]{2}{*}{ Trips (n) } & \multicolumn{3}{|c|}{ Kilometres/trip } & \multicolumn{3}{|c|}{ Minutes/trip } & \multicolumn{3}{|c|}{ Speed (km/hour) } \\
\hline & & $\tilde{x}$ & IQR & $\mathrm{p}$ & $\tilde{x}$ & IQR & $\mathrm{p}$ & $\tilde{x}$ & IQR & $\mathrm{p}$ \\
\hline Weekday $(\mathrm{N}=1185)$ & & & & $<0.001$ & & & $<0.001$ & & & $<0.001$ \\
\hline Go home & 480 & 10.7 & 15.0 & & 30.0 & 25.0 & & 25.8 & 24.6 & \\
\hline Work commute & 313 & 13.7 & 15.3 & & 30.0 & 35.0 & & 30.0 & 24.6 & \\
\hline Drive passenger/school & 236 & 5.0 & 8.1 & & 15.0 & 25.0 & & 21.0 & 17.4 & \\
\hline Meal/shopping/leisure & 91 & 4.9 & 7.4 & & 15.0 & 20.0 & & 24.0 & 22.8 & \\
\hline Other/personal business & 65 & 11.1 & 5.3 & & 20.0 & 27.5 & & 33.0 & 23.4 & \\
\hline Weekend $(\mathrm{N}=880)$ & & & & 0.004 & & & 0.003 & & & 0.163 \\
\hline Go home & 389 & 12.5 & 14.5 & & 20.0 & 20.0 & & 30.6 & 24.6 & \\
\hline Work commute/drive passenger/school & 34 & 12.1 & 12.8 & & 20.0 & 20.0 & & 33.6 & 24.6 & \\
\hline Meal/shopping/leisure & 374 & 11.0 & 13.2 & & 20.0 & 15.5 & & 30.0 & 23.4 & \\
\hline Other work/personal business & 83 & 14.9 & 16.8 & & 30.0 & 20.0 & & 34.2 & 27.0 & \\
\hline
\end{tabular}


Table 6

Binary logistic regression of trip characteristics associated with intention to shift to rail transport on weekday.

\begin{tabular}{|c|c|c|c|c|c|c|c|}
\hline \multirow[t]{2}{*}{ Variable } & \multirow[t]{2}{*}{ B } & \multirow[t]{2}{*}{ SE } & \multirow[t]{2}{*}{ Adj. OR } & \multicolumn{2}{|c|}{$95 \%$ CI OR } & \multirow[t]{2}{*}{ Wald $(\mathrm{df})^{\mathrm{a}}$} & \multirow[t]{2}{*}{$\mathrm{p}$-value } \\
\hline & & & & Lower & Upper & & \\
\hline \multicolumn{8}{|l|}{ Trip duration (minutes) } \\
\hline$\leq 10.00$ & & & 1.000 & & & $34.378(3)^{\mathrm{b}}$ & $<0.001^{\mathrm{b} *}$ \\
\hline $11.00-20.00$ & 0.870 & 0.198 & 2.386 & 1.618 & 3.519 & $19.243(1)$ & $<0.001^{*}$ \\
\hline $21.00-35.00$ & 1.054 & 0.233 & 2.870 & 1.820 & 4.527 & $20.561(1)$ & $<0.001^{*}$ \\
\hline $36.00+$ & 1.435 & 0.254 & 4.199 & 2.552 & 6.911 & $31.876(1)$ & $<0.001^{*}$ \\
\hline \multicolumn{8}{|l|}{ Trip distance $(\mathrm{km})$} \\
\hline$\leq 4.10$ & & & 1.000 & & & $17.223(3)^{b}$ & $0.001^{\mathrm{b} *}$ \\
\hline $4.11-10.00$ & 0.715 & 0.198 & 2.044 & 1.386 & 3.012 & $13.035(1)$ & $<0.001^{*}$ \\
\hline $10.01-18.70$ & 0.677 & 0.239 & 1.967 & 1.231 & 3.143 & $8.008(1)$ & $0.005^{*}$ \\
\hline $18.71+$ & 0.324 & 0.260 & 1.382 & 0.831 & 2.299 & $1.557(1)$ & 0.212 \\
\hline \multicolumn{8}{|l|}{ Vehicle occupancy } \\
\hline 1 & & & 1.000 & & & $5.154(2)^{\mathrm{b}}$ & $0.076^{\mathrm{b}}$ \\
\hline 2 & 0.425 & 0.189 & 1.529 & 1.057 & 2.212 & $5.073(1)$ & $0.024 *$ \\
\hline $3+$ & 0.282 & 0.264 & 1.326 & 0.791 & 2.222 & $1.144(1)$ & 0.285 \\
\hline \multicolumn{8}{|l|}{ Purpose } \\
\hline Go home & & & 1.000 & & & $15.923(4)^{\mathrm{b}}$ & $0.003^{\mathrm{b} *}$ \\
\hline Work commute & 0.162 & 0.157 & 1.176 & 0.865 & 1.598 & $1.068(1)$ & 0.301 \\
\hline Drive passenger/school & 0.036 & 0.189 & 1.037 & 0.715 & 1.502 & $0.036(1)$ & 0.849 \\
\hline Meal/shopping/leisure & -0.375 & 0.263 & 0.687 & 0.411 & 1.150 & $2.040(1)$ & 0.153 \\
\hline Other work/personal business & -0.919 & 0.293 & 0.399 & 0.225 & 0.708 & $9.854(1)$ & $0.002^{*}$ \\
\hline \multicolumn{8}{|l|}{ Child passengers } \\
\hline No & & & 1.000 & & & $9.041(1)^{\mathrm{b}}$ & $0.003^{\mathrm{b} *}$ \\
\hline Yes & -0.735 & 0.246 & 0.479 & 0.296 & 0.777 & $8.912(1)$ & $0.003^{*}$ \\
\hline
\end{tabular}

${ }^{\mathrm{a}}$ Wald test ${ }^{\mathrm{b}}$ Likelihood Ratio (LR) test *significant at $\mathrm{p}<0.05$.

Table 7

Binary logistic regression of trip characteristics associated with intention to shift to rail transport on weekend.

\begin{tabular}{|c|c|c|c|c|c|c|c|}
\hline \multirow[t]{2}{*}{ Variable } & \multirow[t]{2}{*}{ B } & \multirow[t]{2}{*}{$\mathrm{SE}$} & \multirow[t]{2}{*}{ Adj. OR } & \multicolumn{2}{|c|}{$95 \%$ CI OR } & \multirow[t]{2}{*}{ Wald (df) ${ }^{\mathrm{a}}$} & \multirow[t]{2}{*}{ p-value } \\
\hline & & & & Lower & Upper & & \\
\hline Trip duration (minutes) & & & & & & $32.958(3)^{\mathrm{b}}$ & $<0.001^{\mathrm{b} *}$ \\
\hline$\leq 10.00$ & & & 1.000 & & & & \\
\hline $11.00-20.00$ & 0.826 & 0.215 & 2.283 & 1.497 & 3.481 & $14.705(1)$ & $<0.001^{*}$ \\
\hline $21.00-35.00$ & 0.678 & 0.187 & 1.970 & 1.367 & 2.840 & $13.204(1)$ & $<0.001^{*}$ \\
\hline $36.00+$ & 0.984 & 0.190 & 2.676 & 1.845 & 3.882 & 26.939 (1) & $<0.001^{*}$ \\
\hline Child passengers & & & & & & $7.050(1)^{\mathrm{b}}$ & $0.008^{\mathrm{b} *}$ \\
\hline No & & & 1.000 & & & & \\
\hline Yes & -0.376 & 0.142 & 0.687 & 0.520 & 0.907 & $7.014(1)$ & $0.008^{*}$ \\
\hline
\end{tabular}

${ }^{\mathrm{a}}$ Wald test ${ }^{\mathrm{b}}$ Likelihood Ratio (LR) test *significant at $\mathrm{p}<0.05$.

if the traffic congestion in Kuala Lumpur is not resolved soon with an effective public transport system, it is possible that motorcycle use will increase as people switch from using cars to motorcycles instead of public transports. Besides, the higher speed of rail trips compared to car trips could appeal to the car users especially of single occupancy vehicle trips. On the other hand, bus services would need to improve in order to compete with the private vehicles, especially for the weekend trips. The distance of passenger car trips in Kuala Lumpur on the weekend were significantly longer than rail trips, which could be a factor that have prevented these trips from being replaced by rail transport.

The trips for the purpose of driving passenger/school trips on the weekday were significantly shorter than other purposes, as most of the destinations of these trips, such as transit stations, child day care centres, and schools were situated near to housing areas. Besides, the trips for having a meal or leisure activities also had significantly shorter distance, indicating that people preferred to go to areas nearby homes on a working weekday. The lower speed found for the trips in these two purposes supported that most of these trips were made on the local residential roads, which were narrower and reduced driving speeds (Godley, Triggs, \& Fildes, 2004; Lewis-Evans and Charlton, 2006). On the other hand, the trips for other work/personal business, which had the longest trip distance, were made for visiting relatives and friends, and attending events like weddings on the weekend.

The results of binary logistic regressions show that trip characteristics significantly influenced the intention to shift from private vehicles to rail transport in Kuala Lumpur. On the weekday, the intention to shift increased with trip duration, suggesting that people accepted that rail transport could be an effective alternative transport to avoid traffic congestions and save travel time. However, the intention to shift reduced when the transport mode was motorcycles which had the highest speed among all the other transport modes. On the other hand, the reduced intention to shift when trip distance increased may be due to the longer travel time needed by using rail transport compared to using private vehicles. Travel time has always been prioritized compared to travel mode and travel distance in making mode choices (Frank, Bradley, Kavage, Chapman, \& Lawton, 2007; Small, Winston, \& Yan, 2005). In addition, longer distance trips would sometimes require rail transfers, which have been viewed negatively among commuters based on previous research (Guo \& Wilson, 2004; Chowdhury \& Ceder, 2016). The trip distance with the highest potential to shift was between $4 \mathrm{~km}$ to $10 \mathrm{~km}$, which is similar to a study by Wang et al. (2012) on bus rapid transit in China. This finding also reflects the study by Nurdden et al. 
(2007) in Kuala Lumpur that reduced travel time by public transport increased modal shift while increased home to work commute distance increased car use. Such transport pattern implies that higher urban density is needed to reduce the travel distance, and encourage public transport use instead of driving in the city (McIntosh, Trubka, Kenworthy, \& Newman, 2014; Jiang, Gu, Chen, He, \& Mao, 2016).

Besides, the respondents had higher intention to shift when there were two persons in the vehicle. These trips were probably made for driving spouses to work or older children for education. Therefore, if rail services were available, these chauffeuring trips could be shifted (Zwerts, Allaert, Janssens, Wets, \& Witlox, 2010; O'Fallon, Sullivan, \& Hensher, 2004). In addition, the intention to shift was higher for work commute and lower for other work or personal trips, consistent with Wang et al. (2013) but contrary to Limtanakool et al. (2006) and van der Waerden et al. (2008). In the local context, as the other personal trips in this study included attending events like weddings, people may be concerned about getting sweaty from taking public transport after being dressed up to attend the events. Besides, these family trips usually have higher vehicle occupancy which may be more cost effective to drive than to ride the public transport (Paulley et al., 2006). Although the trips for both driving passengers and leisure activities fell within the $4 \mathrm{~km}$ to $10 \mathrm{~km}$ optimal range of distance for modal shift, the leisure trips were shown to be less intended to shift. Therefore, focus should be given to encouraging the modal shift of the driven passengers, which could then affect the modal choice of the drivers themselves (O'Fallon et al., 2004).

For weekend trips, the model on the intention to shift were less predictive with only trip duration and presence of child passengers being the significant factors. This implies that weekend trips were less influenced by the trip characteristics, and higher trip frequency such as the trips on the weekday may have more potential to be shifted to rail transport. Similar to weekday trips, the intention to shift increased with trip duration. However, there were less intention to shift when the trip duration was $21 \mathrm{~min}$ to $35 \mathrm{~min}$ compared to trip duration below $20 \mathrm{~min}$ and above $35 \mathrm{~min}$, which could be a point for further specific study.

As an additional information, we asked about the reasons that individuals would not shift the particular trips to rail transport. The most commonly cited reasons on weekday were: destinations being nearby, having children on the vehicles, and the need to travel flexibly around places due to work requirement. Other reasons include perceiving rail transport as not convenient, preferring motorcycle which is fast and flexible, and the need to carry things with vehicle. For weekend, the reasons most cited were the need to carry things, nearby destinations and having children in the vehicles. Comparably, study by Oliver Ling et al. (2016) on transit oriented development in Kuala Lumpur pointed out that people were discouraged from using public transport due to incomplete route and connectivity, unsatisfactory services and fear of crime.

The characteristics of trips were important to identify the suitable alternative to substitute private motor vehicles in a city. In this study, rail transport has been shown to be the closest alternative in Kuala Lumpur. Using public transport also introduces some walking trips which could increase physical activity and improve the well-being of the commuters (Rissel, Curac, Greenaway, \& Bauman, 2012). This study found that a quarter of the private vehicle trips were within four kilometres, which could be replaced by buses or active transport such as cycling. More studies could be done on the influence of urban design such as the environmental attributes on the way to rail stations, and the locations of shops to encourage rail transport use and utilitarian walking instead of driving for short distance trips. The reduction of these short trips could reduce the exposure to air pollution and traffic injuries especially among the vulnerable school children in the residential and school areas.

The limitation of this study is the recall of the trips by the respondents, especially for the previous weekend which might have introduced non-randomness as people who were interviewed on the particular weekend might have come to the survey location (supermarket) because they had not come on the earlier weekend, causing no trips recorded. This study also did not relate personal characteristics with the intention to shift to rail transport as analysis was performed on the basis of each private vehicle trips. The interpretation of the results has given much speculations on the cultural context of local transport in Kuala Lumpur such as the chauffeuring trips, trips to attend social events, and rail transfers which could be further studied using qualitative methods. In addition, a comprehensive travel survey focusing on the current public transport users may assist in discovering the weakness of the public transport system in Kuala Lumpur for improvement in order to encourage modal shift from the private vehicle users. Although this study uses stated intention as the precursors to the actual behaviour, the intention - behaviour gap remains as its consistency may be influenced by other moderating factors such as habits and the context of the behaviours (Webb \& Sheeran, 2006). Therefore, the results from this study should be used discreetly with validation from other similar studies.

\section{Conclusion}

This study presents the current travel pattern in the corridor of a forthcoming MRT system in the Kuala Lumpur metropolitan area. The characteristics of the trips show an opportunity to substitute private vehicle trips with rail transport in the city. Trip duration, trip distance, trip purpose, vehicle occupancy and the presence of children in vehicle were the important factors that were associated with the population's intention to shift to rail transport on weekday while weekend trips were less influenced by the trip characteristics.

\section{Acknowledgements}

Research was funded by the United Nations University International Institute for Global Health (UNU-IIGH 80814) and the National University of Malaysia (FF-2014-400).

\section{Appendix A. Supplementary data}

Supplementary data associated with this article can be found, in the online version, at http://dx.doi.org/10.1016/j.scs.2017.10.030.

\section{References}

Almselati, A. S. I., Rahmat, R. A. O. K., \& Jaafar, O. (2011). An overview of urban transport in Malaysia. The Social Sciences, 6(1), 24-33.

Babisch, W. (2006). Transportation noise and cardiovascular risk: Updated Review and synthesis of epidemiological studies indicate that the evidence has increased. Noise and Health, 8, 1-29.

Chapman, L. (2007). Transport and climate change: A review. Journal of Transport Geography, 15, 354-367.

Chowdhury, S., \& Ceder, A. (2016). Users' willingness to ride an integrated publictransport service: A literature review. Transport Policy, 48, 183-195.

Chuen, O. C., Karim, M. R., \& Yusoff, S. (2014). 2014. mode choice between private and public transport in klang valley, Malaysia. The Scientific World Journal, 2014.

Corpuz, G. (2007). Public transport or private vehicle: factors that impact on mode choice. 30th australasian transport research forum. November 21, 2016 Available at: http:// atrf.info/papers/2007/2007_Corpuz.pdf.

Department of Statistics Malaysia (2010). Population distribution and basic demographic characteristic report 2010. September 14, 2017) Available at: https://www.dosm. gov.my.

Detailed Environmental Impact Assessment report (EIA) (2011). Klang valley mass rapid transit sungai buloh -Kajang line [Approved by Department of Environment (DOE)].

Frank, L., Bradley, M., Kavage, S., Chapman, J., \& Lawton, T. K. (2007). Urban form, travel time, and cost relationship with tour complexity and mode choice. Transportation. http://dx.doi.org/10.1007/s11116-007-9136-6.

Godley, S. T., Triggs, T. J., \& Fildes, B. N. (2004). Perceptual lane width, wide perceptual road centre markings and driving speeds. Ergonomics, 47, 237-256.

Guo, Z., \& Wilson, N. H. M. (2004). Assessment of the transfer penalty for transit trips: Geographic information System-Based disaggregate modeling approach. transportation research record. Journal of the Transportation Research Board, 10-18.

Institute for Public Health (IPH) (2015). National health and morbidity survey 2015 (NHMS. Methodology and general findings, Vol. I. Ministry of Health. 
Jemali, S. (2011). Getting the public transport policy right. the edge financial daily. [(August 20, 2014) May 3, Available at:] http://www.theedgemalaysia.com/features/185962getting-the-public-transport-policy-right.html.

Jiang, Y., Gu, P., Chen, Y., He, D., \& Mao, Q. (2016). Influence of land use and street characteristics on car ownership and use: Evidence from Jinan, China. Transportation Research Part D. http://dx.doi.org/10.1016/j.trd.2016.08.030.

Kasipillai, J., \& Chan, P. (2008). Travel demand management: lessons for Malaysia. Journal Of Public Transportation, 11(3), 41-55.

Khreis, H., Warsow, K. M., Verlinghieri, E., Guzman, A., Pellecuer, L., Ferreira, A., \& Nieuwenhuijsen, M. (2016). The health impacts of traffic-related exposures in urban areas: Understanding real effects, underlying driving forces and co-producing future directions. Journal of Transport \& Health, 3, 249-267.

Krzyzanowski, M., Kuna-Dibbert, B., \& Schneider, J. (Eds.). (2005). Health effects of transport related air pollution. Copenhagen: World Health Organization.

Kumar, R., \& Electricwala, F. (2014). Impact of proposed modal shift from private users to bus rapid transit system: An indian city case study. International Scholarly and Scientific Research \& Innovation, 8(6), 663-667.

Kwan, S. C., Tainio, M., Woodcock, J., Sutan, R., \& Hashim, J. H. (2017). The carbon savings and health co-benefits from the introduction of mass rapid transit system in Greater Kuala Lumpur, Malaysia. Journal of Transport \& Health. http://dx.doi.org/10. 1016/j.jth.2017.08.003.

Lachapelle, U., Frank, L., Saelens, B. E., Sallis, J. F., \& Conway, T. L. (2011). 2011 Commuting by public transit and physical activity: where you live, where you work, and how you get there. Journal of Physical Activity and Health, 8(Suppl. 1), S72-S82.

Land Public Transport Commission (SPAD) (2013). Greater kuala Lumpur/Klang valley public transport master plan. (August 20, 2014) Available at: http://www.spad.gov. my/projects/national-master-plan/draft-greater-klklang-valley.

Land Public Transport Commission (SPAD) (2014). Public transport usage in the greater Klang Valley region continues to rise. (November 22, 2016) Available at: http://www. spad.gov.my/news-events/media-releases/2014/public-transport-usage-greaterklang-valley-region-continues.

Lewis-Evans, B., \& Charlton, S. G. (2006). Explicit and implicit processes in behavioural adaptation to road width. Accident Analysis \& Prevention, 38(3), 610-617.

Limtanakool, N., Dijst, M., \& Schwanen, T. (2006). The influence of socioeconomic characteristics: Land use and travvel time considerations on mode choice for medium- and longer-distance trips. Journal of Transport Geography, 14, 327-341.

Müggenburg, H., Busch-Geertsema, A., \& Lanzendorf, M. (2015). Mobility biographies: a review of achievements and challenges of the mobility biographies approach and a framework for further research. Journal of transport geography, 46, National Research Center151-163. (October 2, 2014) 2013, Modal Shift in the Boulder Valley 1990-2012. Available at: http://www.walkfriendly.org/assessment/fileupload/ modal-shift -1990-2012-report-2013-1-201307230828. pdf.

McIntosh, J., Trubka, R., Kenworthy, J., \& Newman, P. (2014). The role of urban form and transit in city car dependence: Analysis of 26 global cities from 1960 to 2000. Transportation Research Part D, 33, 95-110.

Ministry of Natural Resources and Environment Malaysia (2011). Second national communication to the UNFCCC. Malaysia: NRE.

Mohamad, J., \& Kiggundu, A. T. (2007). The rise of the private cars in Kuala Lumpur, Malaysia. IATSS Research, 31(1), 69-77.

National Research Center. 2013. Modal Shift in the Boulder Valley 1990 to 2012. City of Boulder: Transportation Division. (November 2, 2017) Available at: http:// assessment.walkfriendly.org/fileupload/modal-shift_-1990-2012-report-2013-1201307230828.pdf.

Nurdden, A., Rahmat, R. A. O. K., \& Ismail, A. (2007). Effect of transportation policies on modal shift from private car to public transport in Malaysia. Journal of Applied Sciences, 7(7), 1014-1018.

O'Fallon, C., Sullivan, C., \& Hensher, D. A. (2004). Contraints affecting mode choices by morning car commuters. Transport Policy, 11, 17-29.

Oliver Ling, H. L., Hasri, N. I. Z., \& Musthafa, S. N. A. (2016). Residents' transportation mode preferences in transit oriented area: A case study of mentari court, petaling jaya, Malaysia. Malaysian Journal of Society and Space, 12(1), 49-60.

Ortúzar, J., de, D., \& Willumsen, L. G. (2001). Modelling transport (3rd ed.). West Sussex, England: John Wiley \& Sons.

Paulley, N., Balcombe, R., Mackett, R., Titheridge, H., Preston, J. M., Wardman, M. R., .. White, P. (2006). The demand for public transport: The effects of fares, quality of service, income and car ownership. Transport Policy, 13(4), 295-306.

Performance management delivery unit (PEMANDU) (2010). Economic transformation program handbook. (August 21, 2014) Available at: http://etp.pemandu.gov.my/ download_centre.aspx.

Racca, D. P., \& Ratledge, E. (2003). Factors that affect and/or can alter modal choice. University of Delaware. (November 21, 2016) Available at: http://sites.udel.edu/ dct/files/2013/10/Rpt.-159-Factors-that-Affect-and-or-Can-Alter-Mode-Choiceyzxqre.pdf.

Rissel, C., Curac, N., Greenaway, M., \& Bauman, A. (2012). Physical activity associated with public transport use-a review and modelling of potential benefits. International Journal of Environmental Research and Public Health, 2012(9), 2454-2478. http://dx. doi.org/10.3390/ijerph9072454.

Small, K. A., Winston, C., \& Yan, J. (2005). Uncovering the distribution of motorists' preferences for travel time and reliability. Econometrica. http://dx.doi.org/10.1111/j. 1468-0262.2005.00619. x.

van der Waerden, P., Timmermans, H., \& Berenos, M. (2008). Trip characteristics and travelers' willingness to change transport mode in favor of public transport. (November 21 , 2016) Available at: www.cvs-congres.nl/cvspdfdocs/cvs08_25. pdf.

Wang, Y., Wang, Z., Li, Z., Staley, S. R., Moore, A. T., \& Gao, Y. (2012). A study of modal shifts to bus rapid transit in chinese cities. Journal of Transportation Engineering. . http://dx.doi.org/10.1061/(ASCE)TE. 1943-5436.0000523.

Wang, Y., Li, L., Wang, Z., Lv, T., \& Wang, L. (2013). Mode shift behavior impacts from the introduction of metro service: Case study of xi'an. China. J. Urban Plann. Dev. 139, 216-225.

Zwerts, E., Allaert, G., Janssens, D., Wets, G., \& Witlox, F. (2010). How children view their travel behaviour: A case study from Flanders (Belgium). Journal of Transport Geography, 18(6), 702-710. http://dx.doi.org/10.1016/j.jtrangeo.2009.10.002. 